\title{
WORKERS LEGAL PROTECTION IMPLEMENTATION WITH A SPECIFIC TIME WORK AGREEMENT AT GRAFITECINDO CIPTA PRIMA COMPANY
}

\author{
Herril Fahmi and Jaelani Sidiq \\ Departement of Law, IBLAM School of Law \\ Jalan Kramat Raya No.25, Jakarta Pusat
}

\begin{abstract}
Abstrack
Implementation of PKWT according to Law no. 13 of 2003 concerning Manpower states that the PKWT work relationship requires a written agreement in Indonesian and may not be for permanent work in the company which, if violated, will result in changing the work relationship to PKWTT. Likewise with the rights to wages, working time and employee participation in the BPJS. Meanwhile, the terms of work are regulated in a Work Agreement or Collective Bargaining Agreement. Workers Union at PT. GCP, namely GSPMII, has succeeded in overseeing the implementation of PKWT in the form of fulfilling work norms and conditions for PKWT workers in companies and also guaranteeing continuity to work at the company. Although there are still violations where the sanctions for violating the PKWT mechanism, namely changing the status to PKWTT, cannot be implemented so that there is a work agreement that always continues, but in the mind of the labor union, it is a solution to guarantee the continuity of work for PKWT workers in the company. This study limits the discussion to the problem of implementing PKWT at PT. GCP is in accordance with Law Number 13 of 2003 concerning Manpower and how the role of PUK GSPMII PT. GCP in overseeing the fulfillment of work norms and conditions and providing guarantees for the continuity of employment of contract workers in the company. This thesis research uses the empirical normative legal method where the authors conduct research on the application of labor law at PT. Grafitecindo Ciptaprima, where the researcher is in charge of the trade union. Employers must comply with the legal rules regarding the PKWT mechanism, including the fulfillment of temporary work norms and conditions for trade unions must have a good understanding and strategy in dealing with the problem of violating the PKWT mechanism, not only prioritizing legal certainty but also but also it would be better if it prioritizes the principles benefit, especially for workers.
\end{abstract}

Keywords: Legal Protection, Work Wages, Working Time 


\title{
PELAKSANAAN PERLINDUNGAN HUKUM PEKERJA DENGAN PERJANJIAN KERJA WAKTU TERTENTU DI PT GRAFITECINDO CIPTA PRIMA
}

\author{
Herril Fahmi dan Jaelani Sidiq
}

\author{
Program Studi Sarjana Hukum, Sekolah Tinggi Ilmu Hukum IBLAM \\ Jalan Kramat Raya No. 25 Jakarta Pusat
}

\begin{abstract}
Intisari
Pelaksanaan PKWT menurut Undang-undang No. 13 Tahun 2003 Tentang Ketenagakerjaan menyatakan bahwa hubungan kerja PKWT mewajbkan adanya perjanjian tertulis dalam Bahasa Indonesia dan tidak boleh untuk pekerjaan yangbersifat tetap di perusahaan yang jika dilanggar berakibat berubahnya hubungan kerja menjadi PKWTT. Demikian juga dengan hak upah, waktu kerja dan kepesertaan pekerja dalam BPJS. Sementara, syarat kerja diatur dalam Perjanjian Kerja ataupun Perjanjian Kerja Bersama. Serikat Pekerja di PT. GCP, yaitu GSPMII telah berhasil mengawal pelaksanaan PKWT berupa pemenuhan norma dan syarat kerja bagi pekerja PKWT di perusahaan dan juga jaminan keberlangsungan bekerja di perusahaan. Walaupun masih ada pelanggaran dimana sanksi pelanggaran mekanisme PKWT yaitu berubahnya status menjadi PKWTT belum bisa dilaksanakan sehingga yang terjadi perjanjian kerja yang selalu berlanjut, namun dalam pemikiran serikat pekerja, itu merupakan solusi bagi jaminan keberlangsungan bekerja bagi pekerja PKWT di perusahaan. Penelitian ini membataskan bahasan pada masalah pelaksanaan PKWT di PT. GCP telah sesuai dengan Undang-undang Nomor 13 Tahun 2003 Tentang Ketenagakerjaan dan bagaimana peran PUK GSPMII PT. GCP dalam mengawal pemenuhan norma dan syarat kerja dan memberikan jaminan keberlangsungan bekerja pekerja kontrak di perusahaan. Penelitian skripsi ini menggunakan metode hukum normatif empiris dimana penulis melakukan penelitian atas penerapan hukum ketenagakerjaan di PT. Grafitecindo Ciptaprima, dimana peneliti berposisi sebagai pengurus serikat pekerja. Pengusaha harus mematuhi aturan hukum tentang mekanisme PKWT, termasuk pemenuhan norma dan syarat kerja sementara bagi serikat pekerja harus mempunyai pemahaman dan strategi yang baik dalam menghadapi permasalahan pelanggaran mekanisme PKWT, tidak hanya mengutamakan kepastian hukum semata tetapi juga tetapi juga akan lebih baik jika lebih mendahulukan asas kemanfaatan, khususnya bagi pekerja.
\end{abstract}

Kata Kunci: Perlindungan Hukum, Upah Kerja, Waktu Kerja 


\section{A. PENDAHULUAN.}

Masih banyak permasalahan ketenagakerjaan di Indonesia, terlebih lagi dalam era modern dimana pertumbuhan perusahaan-perusahaan di Indonesia berkembang dengan pesat seiring dengan kenaikan kebutuhan hidup yang harus ditanggung masyarakat. Pertumbuhan perusahaan ternyata tidak berbanding lurus dengan jumlah pertumbuhan penduduk usia produktif sehingga mengakibatkan penurunan tingkat kesejahteraan penduduk dikarenakan mereka tidak memiliki pendapatan tetap untuk menyokong kelangsungan hidupnya. ${ }^{1}$ Kondisi ini merupakan tantangan bagi tujuan keberadaan Negara Kesatuan Republik Indonesia.

Karena itu, pemerintah mengeluarkan Undang-undang Nomor 13 Tahun $2003 \quad$ Tentang Ketenagakerjaan yang diharapkan dapat mengatur sehingga terpenuhinya hak-hak pekerja dan perlindungan yang mendasar bagi tenaga kerja dan disaat yang bersamaan dapat mewujudkan kondisi yang aman bagi pengembangan dunia usaha. Dengan kata lain, diharapkan keseimbangan atau keserasian hubungan antara pengusaha dengan pekerja dapat tercipta sehingga keberlangsungan usaha dan ketenangan bekerja dalam rangka meningkatkan produktifitas kerja dan kesejahteraan tenaga kerja dapat tercapai.

Hukum ketenagakerjaan harus menjaga ketertiban, keamanan dan keadilan bagi pihak-pihak yang terkait dalam proses produksi, untuk dapat mencapai ketenangan bekerja dan kelangsungan berusaha dengan dilatar belakangi adanya pengalaman selama ini yang kerap kali terjadi kesewenangwenangan pengusaha terhadap pekerja/buruh. Untuk itu diperlukan suatu perlindungan hukum secara komperehensif dan kongkret dari pemerintah. $^{2}$

Subjek utama dalam hubungan industrial adalah pekerja dan pengusaha. Antara keduanya dihubungkan dengan adanya perjanjian kerja antara pengusaha dan pekerja. ${ }^{3}$ Perjanjian kerja adalah perjanjian antara seorang majikan yang ditandai dengan ciri-ciri adanya upah atau gaji tertentu, adanya hubungan atas bawah, yakni suatu hubungan atas dasar pihak yang satu, majikan berhak memberikan perintah yang harus ditaati oleh pihak lainnya.

Pekerja/buruh merupakan mitra kerja pengusaha yang sangat penting dalam proses produksi dalam rangka meningkatkan kesejahteraan pekerja/buruh dan keluarganya, menjamin kelangsungan kerja, dan meningkatkan kesejahteraan masyarakat Indonesia pada umumnya.

Jurnal Hukum Perdata Univ. Gadjah Mada Vol. 2, No. 2, November 2013 hal. 2

2 Abdul Khakim, Dasar-Dasar Hukum Ketenagakerjaan Indonesia, Cet. 4 (Bandung: Citra Aditya bakti,2014), hal 8.

${ }^{3}$ Adrian Suteja, Hukum Perburuhan, (Jakarta: Sinar Grafika, 2009) hal. 46.

${ }^{4}$ Asyhadie Zaeni. Hukum Kerja Hukum Ketenagakerjaan Bidang Hubungan Kerja, (Jakarta:Raja Grafindo Persada, 2013), hal. 15 
Nilai-nilai yang terkandung dalam UUD 1945 dan Pancasila dalam hubungan kerja antara pekerja dan pengusaha adalah bebas, dalam artian seorang pekerja tidak boleh diperlakukan seperti budak. Segala macam bentuk perbudakan, penghambaan, dan peruluran dilarang karena memang tidak sesuai dengan UUD 1945 dan Pancasila. Namun, secara sosiologis pekerja/buruh tidaklah bebas sebagai seorang yang tidak mempunyai bekal hidup. Karena bermodal tenaganya saja seorang pekerja/buruh kadangkala terpaksa menerima hubungan kerja dengan pengusaha mestipun hubungan itu memberatkan pekerja/buruh sendiri. ${ }^{4}$

Hubungan kerja terbentuk sebagai akibat adanya kesepakatan antara pemberi kerja dan pekerja. Kesepakatan itu menimbulkan hak dan kewajiban antara kedua belah pihak yang membuatnya. Kesepakatan merupakan awal dari terciptanya perjanjian kerja yang akhirnya melahirkan hubungan kerja. Perjanjian kerja adalah suatu perjanjian yang dibuat antara pekerja secara perseorangan dengan pengusaha yang pada intinya memuat hak dan kewajiban masing-masing pihak. ${ }^{5}$

Perjanjian kerja dapat dibagi menjadi 2 (dua), yaitu:

1. Perjanjian kerja untuk waktu tidak tertentu (PKWTT), adalah perjanjian kerja antara pekerja/buruh dengan pengusaha untuk mengadakan hubungan kerja yang bersifat tetap. Dalam praktek, pekerja dengan sistem ini dikenal dengan sebutan pekerja tetap atau pekerja permanen.

2. Perjanjian kerja untuk waktu tertentu (PKWT), adalah perjanjian kerja antara pekerja/buruh dengan pengusaha untuk mengadakan hubungan kerja dalam waktu tertentu atau pekerjaan tertentu, ${ }^{6}$ yang dikenal dengan sebutan pekerja kontrak.

Undang-undang nomor 13 Tahun 2003 Tentang Ketenagakerjaan memberikan mekanisme pelaksanaan perjanjian kerja, khususnya bagi pekerja dengan perjanjian kerja waktu tertentu (PKWT) yang jika dilanggar maka berdampak berubahnya hubungan kerja. Sementara Pasal 2 Keputusan Menteri Tenaga Kerja dan Transmigrasi Nomor 100 Tahun 2004 menyatakan:

"Syarat kerja yang diperjanjikan dalam PKWT, tidak boleh lebih rendah daripada ketentuan dalam peraturan perundang-undangan yang berlaku."

Pengertian pasal diatas adalah semua pekerja yang memiliki hubungan kerja berdasarkan Perjanjian Kerja untuk Waktu Tertentu (PKWT) dengan pengusaha, apapun statusnya berhak untuk mendapatkan syaratsyarat kerja sebagaimana aturan ketenagakerjaan yang berlaku baik berupa perlakuan, kesempatan kerja maupun hak lainnya.

\footnotetext{
Suwanto, Hubungan Industrial Dalam praktek, Cet. 1 (Jakarta: AHII, 2003) hal. 42.

${ }^{6}$ Pasal 1 Angka 1 Keputusan Menteri Tenaga Kerja dan Transmigrasi Nomor 100 Tahun 2004

Tentang Ketentuan Pelaksanaan Perjanjian Kerja Waktu Tertentu.
} 
Akan tetapi dalam pelaksanaannya, pekerja yang berstatus pekerja kontrak kerap mendapatkan perlakukan yang berbeda dibandingkan dengan pekerja tetap. Seringkalipekerja kontrak "harus" menerima syarat kerja yang dibawah ketentuan aturan yang berlaku. Pekerja kontrakpun diharuskan menerima pemutusan hubungan kerja (PHK) saat masa kontrak kerjanya berakhir. Kondisi inipun terjadi di PT. Grafitecindo CiptaPrima (PT. GCP) masa lalu sebelum hadirnya PUK GSPMII PT. GCP, dimana pekerja kontrak yang terdiri atas pekerja PKWT terpaksa menerima syarat kerja dibawah ketentuan yang berlaku.

Saat ini, di PT. GCP masih terdapat pekerja PKWT yang terdiri atas pekerja kontrak berdasarkan waktu dan pekerja harian lepas. Namun sarat kerja, upah serta jaminan keberlangsungan bekerja bagi pekerja kontrak tersebut jauh lebih baik. Pekerja mendapatkan upah sebagaimana upah minimum yang berlaku. Pekerja mendapatkan tunjangan makan dan uang transport sebagaimana pekerja dengan status lainnya. Demikian juga kepesertaan dalam program Badan Penyelenggara Jaminan Sosial (BPJS), pekerja kontrak berikut keluarganya tercatat sebagaipeserta.

Berdasarkan uraian diatas, peneliti akan membahas tentang: bagaimana perlindungan hukum bagi pekerja waktu tertentu (pekerja kontrak) di PT. GCP, perlindungan hukum yang meliputi mekanisme perjanjian kerja serta kondisi kerja bagi pekerja dengan perjanjian kerja waktu tertentu dan strategi PUK GSPMII PT. GCP dalam melindungi pekerja waktu tertentu di PT. GCP.

Dengan uraian latar belakang diatas, maka rumusan masalah yang akan dibahas dalam penelitian ini adalah:

1. Apakah pelaksanaan pekerja waktu tertentu di PT. Grafitecindo Ciptaprima telah sesuai dengan Undang-undang Nomor 13 Tahun 2003 Tentang Ketenagakerjaan?

2. Apa yang mendasari langkah PUK GSPMII PT. Grafitecindo Ciptaprima dalam melindungi pekerja waktu tertentu di perusahaan?

\section{B. METODE PENELITIAN.}

1. Jenis Penelitian.

Metode yang peneliti gunakan dalam penulisan ini adalah normatif empiris dimana penulis melakukan penelitian atas penerapan hukum ketenagakerjaan tentang pekerja waktu tertentu di PT. Grafitecindo Ciptaprima, dimana peneliti berposisi sebagai pengurus serikat pekerja, dengan berpedoman Undang-undang Nomor 13 Tahun 2003 Tentang Ketenagakerjaan yang diperkuat dengan aturan pelaksana yaitu Keputusan Menteri Tenaga Kerja dan Transmigrasi Republik Indonesia nomor 100 Tahun 2014 tentang Ketentuan Pelaksanaan Perjanjian Kerja Waktu Tertentu.

Metode penelitian hukum normatif empiris ini pada dasarnya merupakan penggabungan antara pendekatan hukum normatif dengan adanya penambahan berbagai unsur empiris. Metode penelitian normatifempiris mengenai implementasi ketentuan hukum normatif (undangundang) dalam aksinya pada setiap peristiwa hukum tertentu yang terjadi di dalam suatu masyarakat. Dengan kategori Non judicial Case Study, yaitu penelitian dengan pendekatan studi kasus hukum yang tanpa konflik 
sehingga tidak ada campur tangan dengan pengadilan. ${ }^{7}$

7 idtesis.com metode penelitian hukum empiris dan normatif, https://idtesis.com disadur pada 6September 2020 Pukul 13.00 WIB

1. Sumber Data.

Sumber data yang dipakai dalam penelitian ini terdiri dari:

(a) Data Primer sebagai data utama yang akan dibahas. Data tersebut merupakan dari pengalaman yang peneliti alami dengan kapasitas peneliti sebagai pengurus serikat pekerja di PT. GCP, sebuah perusahaan yang ada di kawasan Industri Jababeka Tahap I Cikarang Kab. Bekasi Jawa Barat terkait penggunaan pekerja PKWT di perusahaan.

(b)

Data Sekunder yang terdiri atas:

i)
Primer, merupakan bahan hukum yang didapat dari hukum positif yang berlaku di Indonesia berupa peraturan perundang-undangan yang berlaku dan berhubungan dengan obyek penelitian.

Bahan Hukum Sekunder, yaitu bahan hukum yang memberikan penjelasan mengenai perlindungan bagi pekerja yang ada di perusahaan yang mengalami peralihan kepemilikan. Bahan-bahan ini berupa pendapat ahli, keilmuan, dan pengalaman peneliti sendiri.

ii)

$$
\begin{aligned}
& \text { Bahan hukum } \\
& \text { tertier, yaitu bahan yang penulis } \\
& \text { dapat dari Makalah, Koran, } \\
& \text { ensiklopedia, dan internet. } \\
& \text { 2. Cara Pengumpulan Data. } \\
& \text { Cara pengumpulan data }
\end{aligned}
$$
dilakukan dengan studi kepustakaan, yaitu suatu metode pengumpulan data dengan mencari, menemukan dan mempelajari bahan berupa buku-buku yang berkaitan dengan obyek penelitian sehingga didapat data-data yang mendukung hasil studi kasus yang dilakukan.

3. Analisa Data.

Tehnik analisis data menggunakan metode kualitatif dengan menganalisa data berdasarkan peraturan perundang-undangan yang berlaku. Metode kualitatif yaitu cara pengolahan data yang didasarkan pada pengukuran masalah dengan mengacu pada peraturan perundang-undangan.

C. Hasil Penelitian Dan Pembahasan

1. Pelaksanaan Perjanjian Kerja Waktu Tertentu Di PT. Grafitecindo Cipta Prima.

\subsection{Pelaksanaan PKWT}

Berdasarkan UU No. 13 Tahun 2003 Tentang Ketenagakerjaan.

Menurut Guus Heerma Van Voos, ${ }^{8}$ perjanjian kerja yang membentuk landasan dari hukum perburuhan pada asasnya adalah perjanjian keperdataan. Namun Undang-undang Ketenagakerjaan yang mengatur kontrak demikian harus kita cakupkan ke dalam hukum publik.

8 Agusmidah dkk. Bab-Bab Tentang Hukum Perburuhan Indonesia. (Denpasar: Pustaka Larasan,2012) hal. 8. 
Dalam Keputusan Menteri Tenaga Kerja dan Transmigrasi Republik Indonesia Nomor 100 Tahun 2004 Tentang Ketentuan Pelaksanaan Perjanjian Kerja Waktu Tertentu, Pelaksanaan PKWT dapat dibagi menjadi beberapa bentuk, yaitu:

1) PKWT untuk pekerjaan yang sekali selesai atau sementara sifatnya yang penyelesaiannya paling lama 3 (tiga) tahun.

2) PKWT untuk pekerjaan yang bersifat musiman, yang pelaksanaannya tergantung pada musim atau cuaca. 9 Dalam Penjelasan Pasal 59 Ayat (2) Undang-undang Nomor 13 Tahun 2003 Tentang Ketenagakerjaan dinyatakan bahwa pekerjaan yang bukan musiman adalah pekerjaan yang tidak tergantung cuaca atau suatu kondisi tertentu. Adanya frase kata "kondisi tertentu" dalam penjelasan pasal ini merujuk pada suatu keadaan yang kejadiannya bersifat periodik. Selain itu, pekerjaan yang dilakukan untuk memenuhi pesanan atau target tertentu juga dapat dikategorikan sebagai pekerjaan yang bersifat musiman. Akan tetapi, pengkategorian ini memiliki syarat bahwa pekerja kontrak hanya untuk pekerjaan yang sifatnya merupakan pekerjaan tambahan di perusahaan. 10

3) PKWT untuk pekerjaan yang berhubungan dengan produk baru, kegiatan baru, atau produk tambahan yang masih dalam penjajakan atau percobaan di perusahaan.
4) PKWT harian lepas, ialah pegawai yang hanya menerima penghasilan apabila pegawai yang bersangkutan bekerja, berdasarkan jumlah hari kerja, jumlah unit hasil pekerjaan yang dihasilkan atau menyelesaikan suatu jenis pekerjaan yang diminta oleh pemberi kerja. Sistem Pekerja harian lepas hanya untuk waktu 21 (dua puluh satu) hari kerja dalam 1 (satu) bulan dengan maksimal lamanya bekerja adalah selama 3 (tiga) bulan.

\subsection{Mekanisme PKWT \& Akibat Pelanggarannya.}

Mekanisme perjanjian kerja waktu tertentu adalah bagian-bagian yang harus ada dalam sebuah perjanjian kerja waktu tertentu agar sesuai dengan tujuan Pembangunan ketenagakerjaan. Mekanisme perjanjian kerja waktu tertentu sesuai dengan aturan ketenagakerjaan meliputi:

5) Jenis pekerjaan PKWT

Perjanjian kerja untuk waktu tertentu merupakan perjanjian yang diadakan untuk menjalin hubungan dalam waktu tertentu atau pekerjaan tertentu yang hanya dapat dilaksanakan untuk pekerjaan yang menurut sifat atau jenisnya adalah sementara waktu dan sesudahnya akan berakhir. Hal ini menyiratkan bahwa PKWT hanyalah untuk pekerjaan yang akan selesai dalam waktu tertentu. Oleh karena itu jenis pekerjaan dapat dilaksanakan untuk pekerjaan yang bersifat tidak tetap.

Yang dimaksud dengan pekerjaan yang bersifat tetap adalah pekerjaan yang sifatnya terus menerus, tidak terputus-putus, tidak dibatasi waktu dan

\footnotetext{
9 Pasal 4 Ayat (1) Undang-undang Nomor 13
} 
IBLAM LAW REVIEW

SEKOLAH TINGGI ILMU HUKUM IBLAM

Vol 1 No 1 2021, Hal 132-162

Tahun 2003 Tentang Ketenagakerjaan. 
merupakan bagian dari suatu proses produksi dalam satu perusahaan atau pekerjaan yang bukan musiman. Sementara pekerjaan yang bukan musiman adalah pekerjaan yang tidak tergantung cuaca atau suatu kondisi tertentu. ${ }^{11}$

6) Adanya Perjanjian Kerja.

Aturan menyatakan bahwa dalam hubungan kerja waktu tertentu mengharuskan adanya perjanjian kerja antara pengusaha dengan pekerja secara tertulis, dibuat dalam bahasa Indonesia, 12 menggunakan huruf latin dan dibuat 2 (dua) rangkap yang dipegang masingmasing oleh pengusaha dan pekerja. Khusus bagi pekerja dengan status harian lepas, perjanjian kerja dapat dibuat antara pengusaha dengan beberapa pekerja (pekerja secara kolektif).

7) Lamanya waktu perjanjian kerja.

Dalam Perjanjian Kerja untuk pekerjaan yang sekali selesai atau sementara sifatnya harus dicantumkan batasan waktu dari perjanjian kerja dinyatakan selesai, berdasarkan waktu selesainya pekerjaan tersebut. Perjanjian kerja dapat diperpanjnag atau diperbarui. ${ }^{13}$ Dibuat untuk waktu maksimal 2 (dua) tahun dan dapat diperpanjang untuk 1 (satu) tahun berikutnya, 14 atau maksimal 3 (tiga) tahun dan jika pekerjaan tersebut tidak selesai, boleh diperbarui untuk waktu 2 (dua) tahun lagi. ${ }^{15}$ Jika pekerjaan yang diperjanjikan dapat diselesaikan lebih cepat dari waktu yang diperjanjikan, maka demi hukum atau secara otomatis perjanjian kerja berakhir. ${ }^{16}$ Masa pembaruan mensyaratkan adanya jeda waktu selama 30 (tiga puluh) hari dimana antara pekerja dengan pengusaha tidak boleh terikat dalam satu hubungan kerja. Jika pekerjaan yang diperjanjikan dapat diselesaikan lebih cepat dari waktu yang diperjanjikan, maka demi hukum atau secara otomatis perjanjian kerja berakhir. ${ }^{17}$

Perjanjian kerja untuk PKWT yang berhubungan dengan produk baru perjanjian kerja paling lama 2 (dua) tahun dan dapat diperpanjang untuk masa 1 (satu) tahun lagi. 18 Adapun pekerjaan yang dilakukan haruslah pekerjaan diluar kegiatan atau diluar pekerjaan yang biasa dilakukan perusahaan. 19 Untuk pekerja harian lepas, lamanya pekerjaan adalah 21 (dua puluh satu) hari kerja dalam 1 (satu) bulan dengan maksimal waktu selama 3 (tiga) bulan. 


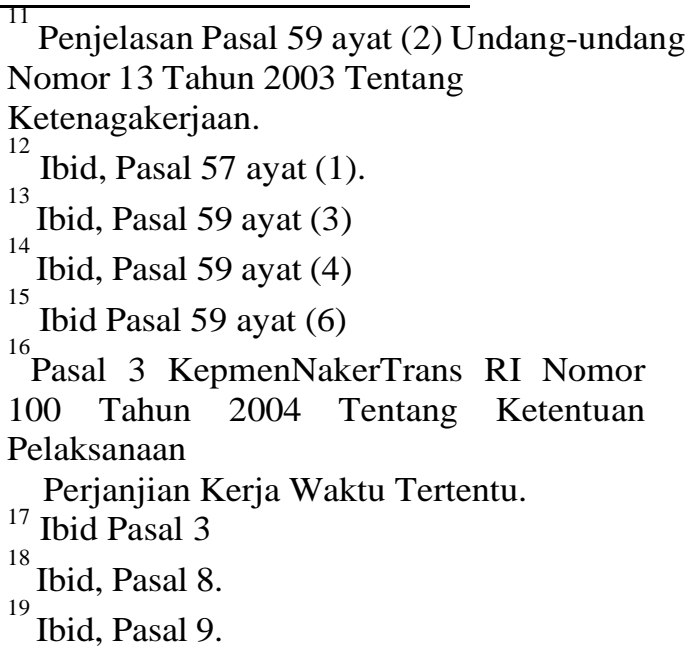

Walaupun ada "asas kebebasan berkontrak", yakni suatu asas yang menyatakan bahwa setiap orang pada dasarnya boleh membuat kontrak (perjanjian) yang berisi berbagai macam perjanjian namun, perjanjian tersebut tidak boleh bertentangan dengan UndangUndang, kesusilaan, dan ketertiban umum. ${ }^{20}$ Ketentuan perjanjian kerja yang ada hubungan kerja atau ketenagakerjaan bukan merupakan bagian dari hukum perjanjian, oleh karena itu dikatakan bahwa ketentuan perjanjian kerja bukan hukum pelengkap. Hal ini berarti ketentuan perjanjian kerja bersifat memaksa artinya ketentuan perjanjian kerja dalam hukum ketenagakerjaan tersebut wajib ditaati atau diikuti. 21

Aturan ketenagakerjaan memberikan batasan-batasan dalam pelaksanaan perjanjian kerja untuk waktu tertentu. Sebagaimana aturan hukum pada umumnya, aturan ketenagakerjaan juga memberikan sanksi atau akibat hukum jika batasan- batasan itu dilanggar. Dalam pelaksanaan perjanjian kerja untuk waktu tertentu, sanksi atau akibat dari pelanggarannya adalah sebagai berikut:

1. Syarat-syarat kerja dalam perjanjian kerja waktu tertentu tidak boleh lebih rendah dari ketentuan peraturan perundangundangan yang berlaku, 22 baik dari segi upah, perlakukan, maupun dalam pemenuhan alat keselamatan dan kesehatan kerja.

Jika dalam perjanjian kerja untuk waktu tertentu memuat syarat kerja dibawah peraturan perundang-undangan, maka perjanjian kerja tersebut dikesampingkan dan dalam pemberlakuan yang dipakai adalah syarat kerja sebagaimana aturan yang berlaku.

2. Perjanjian kerja yang tidak memenuhi sarat subyektif, yaitu tidak adanya kesepakatan para pihak atau tidak adanya kemampuan atau kecakapan melakukan perbuatan hukum, maka perjanjian kerja dapat dibatalkan. Hal ini berlaku bagi pengusaha yang mempekerjakan anak-anak yang perjanjian kerjanya tidak menyertakan kuasa dari orangtua atau wali pekerja.

3. Perjanjian kerja yang tidak memenuhi sarat obyektif, yaitu tidak adanya pekerjaan atau pekerjaan yang diperjanjikan bertentangan dengan ketertiban umum, kesusilaan, dan peraturan perundang-undangan yang berlaku, maka perjanjian kerja batal demi hukum. Misalnya perjanjian kerja waktu tertentu yang tidak dibolehkan untuk pekerjaan yang bersifat tetap diperusahaan tetapi dalam pelaksanaannya pekerja kontrak ditempatkan di pekerjaan utama dan tetap di perusahaan termasuk dalam perjanjian kerja yang tidak 
memenuhi syarat obyektif.

4. Isi perjanjian kerja tidak boleh bertentangan dengan peraturan perusahaan, perjanjian kerja bersama dan peraturan perundangundangan yang berlaku. Jika isi perjanjian kerja bertentangan dengan aturan diatasnya, maka isi perjanjian kerja tersebut dinyatakan tidak berlaku dan yang otomatis berlaku adalah aturan yang ada diatasnya, baik Peraturan Perusahaan, PKB, maupun peraturan perundang-undangan.

5. Perjanjian kerja untuk waktu tertentu yang dibuat tidak tertulis dinyatakan sebagai perjanjian kerja untuk waktu tidak tertentu. Dengan artian bahwa hubungan kerja berubah menjadi pekerja tetap (kartap).

6. Perjanjian kerja untuk waktu tertentu tidak dapat mensyaratkan adanya masa percobaan. Jika ada, maka masa percobaan yang disyaratkan batal demi hukum.

7. Perjanjian kerja untuk waktu tertentu hanya dapat dibuat untuk pekerjaan yang jenis, sifat dan kegiatan pekerjaannya akan selesai dalam waktu tertentu. Adapun pekerjaan itu meliputi pekerjaan yang sekali selesai atau sementara sifatnya, pekerjaaan yang diperkirakan selesai dalam waktu paling lama 3 (tiga) tahun, pekerjaan yang bersifat musiman, atau pekerjaan yang berhubungan dengan produk baru, kegiatan baru, atau produk tambahan yang bersifat percobaan atau penjajakan. Jadi Perjanjian kerja untuk waktu tertentu tidak dapat dilaksanakan bagi pekerjaan yang bersifat tetap. Jika dilanggar, maka hubungan kerja menjadi tetap.

8. Perjanjian kerja untuk waktu tertentu dapat diperpanjang 1 (satu) kali untuk waktu maksimal 1 (satu) tahun. Perpanjangan harus diberitahukan secara tertulis 7 (tujuh) hari sebelum waktu perjanjian kerja berakhir. Jika dilanggar maka hubungan kerja menjadi Perjanjian kerja untuk waktu tidak tertentu (PKWTT).

9. Perjanjian kerja untuk waktu tertentu dapat diperbaharui 1 (satu) kali untuk waktu maksimal selama 2 (dua) tahun dengan syarat adanya masa jeda selama 30 (tiga puluh) hari. Perlanggaran berakibat hubungan kerja berubah menjadi Perjanjian kerja untuk waktu tertentu (PKWTT).

10. Apabila salah satu pihak mengakhiri hubungan kerja sebelum berakhirnya jangka waktu yang telah disepakati, maka pihak tersebut diwajibkan membayar ganti rugi kepada pihak lain sebesar upah pekerja sampai batas waktu berakhirnya jangka waktu perjanjian kerja.

\footnotetext{
${ }^{20}$ Djumadi. Hukum Perburuhan Perjanjian Kerja. (Jakarta: Raja Grafindo Persada, 1999) hal. 10.

${ }^{21}$ Hardijan Rusli, Hukum ketenagakerjaan, (Jakarta: Ghalia Indonesia, 2004) hal. 70.

${ }^{22}$ Pasal 2 Ayat (1) Kepmenakerstrans No. 100 Tahun 2004.
} 
Adapun sanksi atas pelanggaran pelaksanaan Perjanjian Kerja untuk Waktu Tertentu (PKWT) bertujuan memberikan perlindungan bagi pekerja sehingga pekerja mendapatkan jaminan keberlangsungan bekerja di perusahaan tersebut.

\subsection{Norma Dan Syarat Kerja}

\section{PKWT.}

Menurut Mohd. Syaufii Syamsuddin, 23 hubungan kerja terjadi karena adanya perjanjian antara pengusaha dan pekerja yang memuat syarat-syarat kerja, hak dan kewajiban para pihak. Undangundang No. 13 Tahun 2003 memuat beberapa hak dan kewajiban bagi para pihak di dalamnya, yaitu pekerja dan pengusaha. Hak dan kewajiban para pihak yang diatur dalam peraturan perundang-undangan lebih dikenal dengan sebutan norma kerja. Sementara syarat kerja merupakan hak dan kewajiban yang diatur dalam Perjanjian Kerja (PK), Peraturan Perusahaan (PP) maupun Perjanjian Kerja Bersama (PKB). Syarat kerja bisa merupakan norma kerja yang juga diatur dalam PK, PP atau PKB yang nilainya melebihi atau minimal sama dengan norma kerja. Norma kerja sebagai hak pekerja yang terdapat dalam Undang-undang No. 13 Tahun 2003

Tentang ketenagakerjaan berupa:

1. Perlakuan yang sama tanpa diskriminasi dari pengusaha (Pasal 6).

Hak yang sama mendapatkan pelatihan guna meningkatkan dan mengembangkan kompetensi kerja sesuai dengan bakat, minat dan kemampuan (Pasal 11 \& 12) dan memperoleh pengakuan kompetensi kerja setelah mengikuti pelatihan kerja.
(Pasal 18)

2. Hak dan kesempatan yang sama untuk memilih, mendapatkan, atau pindah pekerjaan dan memperoleh penghasilan yang layak. (Pasal 31)

3. PKWT yang diputus perjanjian kerjanya sebelum berakhirnya masa kontrak berhak mendapatkan kompensasi ganti rugi sebesar upah pekerja sampai batas waktu berakhirnya jangka waktu perjanjian kerja. (Pasal 62)

4. Pekerja berhak mendapatkan Surat Pengangkatan sebagai PKWTT jika PKWT tidak berbentuk tertulis (hanya secara lisan). (Pasal 63 ayat (1))

5. Pekerja wanita yang berusia dibawah 18 tahun atau sedang hamil tidak boleh dipekerjakan antara pukul 23.00 sampai dengan pukul 07.00. (Pasal 76); bagi pekerja wanita berhak mendapatkan perlindungan berupa:

1. Mendapatkan makanan dan minuman bergizi,

2. Terjaga kesusilaan dan keamanan selama di tempat kerja,

3. Serta mendapatkan angkutan antar jemput.

6. Pekerja wanita berhak untuk cuti haid, cuti melahirkan dan cuti keguguran serta diberi kesempatan sepatutnya untuk menyusui anaknya jika hal itu harus dilakukan selama waktu kerja..

7. Pekerja hanya wajib bekerja selama 7 (tujuh) jam 1 (satu) 
hari (6 (enam) hari kerja dalam 1 (satu) minggu atau 8 (delapan) jam 1 (satu) hari (untuk 5 (lima) hari kerja dalam 1 (satu) minggu dan 40 (empat puluh) jam 1 (satu) minggu. (Pasal 77). Pekerja berhak diperhitungkan bekerja lembur jika melebihi aturan waktu kerja dengan upah perhitungan upah lembur sesuai ketentuan.

8. Pekerja berhak mendapatkan istirahat dan cuti. (pasal 79)

9. Pekerja berhak mendapatkan kesempatan secukupnya untuk melaksanakan ibadah yang diwajibkan oleh agamanya. (Pasal 80)

10. Setiap pekerja berhak memperoleh perlindungan atas keselamatan dan kesehatan kerja; moral dan kesusilaan; dan perlakuan yang sesuai dengan harkat dan martabat manusia serta nilai nilai agama.

11. Setiap pekerja berhak memperoleh penghasilan atau upah yang layak guna memenuhi penghidupan. (Pasal 88)

12. Hak didahulukan upah dan hak lainnya jika perusahaannya dinyatakan pailit atau dilikuidasi. (Pasal 95 ayat (4))

13. Setiap pekerja dan keluarganya berhak untuk memperoleh jaminan sosial tenaga kerja. Adapun jaminan sosial tenaga kerja saat ini dikelola oleh BPJS.

14. Pekerja berhak membentuk atau menjadi anggota serikat pekerja (pasal 104)

15. Pekerja berhak untuk mengadakan mogok kerja. (pasal 137)

16. Pekerja berhak menerima kompensasi berupa uang pesangon dan atau uang penghargaan masa kerja dan uang penggantian hak yang seharusnya diterima jika di-PHK oleh pengusaha. (Pasal 156)

17. Pekerja berhak mengajukan gugatan ke lembaga penyelesaian perselisihan hubungan industrial atas PHK yang dilakukan pengusaha. (Pasal 171)
Mohd. Syaufii Syamsuddin. Perjanjian-
Perjanjian Dalam Hubungan Industrial.
(Jakarta: Sarana Bhakti Persada, 2005) hal. 55 


\subsection{Pelaksanaan PKWT Di}

\section{PT. GCP.}

Pelaksanaan PKWT di PT. GCP dapat dibagi menjadi 2 (dua) periode, yaitu:

\section{A. Periode sebelum berdirinya PUK GSPMII PT. GCP.}

Dalam periode ini, sangat banyak terjadi pelanggaran mekanisme pelaksanaan PKWT yang dilakukan perusahaan. Adapun pelanggaran tersebut berupa:

1. Perjanjian Kerja Pekerja Waktu Tertentu. Pelanggaran terhadap perjanjian kerja waktu tertentu di PT. GCP masa sebelum berdirinya PUK GSPMII berupa:

1) Tidak ada perjanjian kerja tertulis bagi pekerja harian lepas.

2) Bagi pekerja dengan perjanjian waktu tertentu, tidak diberikan salinan PK, dalam artian, PK hanya dibuat 1 (satu) rangkap dan dipegang oleh Manajemen.

3) Perjanjian Kerja waktu tertentu tidak dilaporkan ke instansi terkait.

2. Jenis Pekerjaan Pekerja Waktu Tertentu.

Sesuai aturan yang berlaku, pekerja waktu tertentu hanya dapat dipergunakan untuk pekerjaan yang jenisnya bukan pekerjaan utama atau pekerjaan tetap di perusahaan. Sementara, di PT. GCP, seluruh pekerja waktu tertentu baik pekerja kontrak, harian lepas, outsourching maupun borongan dipekerjakan di bgaian yang merupakan pekerjaan utama di perusahaan.

3. Lamanya Perjanjian Kerja

Jika dilihat dari masa waktu perjanjian kerja waktu tertentu, maka sangat jelas bahwa untuk PKWT hanya dapat dipergunakan untuk waktu paling lama 3 (tiga) tahun atau 4 (empat) tahun dengan jeda selama 1 (satu) bulan. Sementara untuk pekerja harian lepas untuk waktu 21 (dua puluh satu) hari kerja selama 3 (tiga) bulan berturutturut. Akan tetapi, di PT. GCP, hampir mayoritas pekerja PKWT, baik kontrak perusahaan maupun harian lepas telah lama bekerja, bahkan ada yang telah bekerja selama 10 (sepuluh) tahun.

\section{B. Periode setelah berdirinya PUK GSPMII PT. GCP.}

Dimasa setelah berdirinya PUK GSPMII PT. GCP, tepatnya di akhir tahun 2012, pembenahan Perjanjian Kerja ini dimulai. Untuk pekerja Harian lepas, dibuat PK untuk setiap pekerjanya. Demikian juga untuk pekerja kontrak, PK dibuat sesuai dengan lamanya waktu perjanjian. $^{24}$

Terkait tentang jenis pekerjaan PKWT, pelanggaran tentang hal ini belum bisa diperbaiki oleh PUK GSPMII PT. GCP sampai saat ini. Umumnya, jenis pekerjaan yang dikerjakan oleh pekerja PKWT di PT. GCP masih merupakan pekerjaan yang bersifat tetap dan termasuk pekerjaan utama. Hanya untuk pekerja PKWT yang baru direkrut perusahaan, yang bisa dikatakan sesuai dengan jenis pekerjaan bagi PKWT, yaitu pekerjaan yang merupakan produk baru di perusahaan. 25

\footnotetext{
${ }_{24}^{24}$ Wawancara dengan Suherman, Op. Cit.
${ }^{25}$ Ibid.
} 


\begin{tabular}{|c|c|c|}
\hline Dem & nikian & perihal \\
\hline lamanya & kerja & pekerja \\
\hline $\begin{array}{l}\text { PKWT, } \\
\text { belum }\end{array}$ & $\begin{array}{l}\text { PUK GSPMII } \\
\text { bisa }\end{array}$ & $\begin{array}{l}\text { PT. GCP } \\
\text { mengawal }\end{array}$ \\
\hline aksan & sesuia & dengan \\
\hline & lagaker & \\
\hline
\end{tabular}

Mekanisme PKWT di PT. GCP

\begin{tabular}{|c|c|c|c|}
\hline \multirow[t]{2}{*}{$\begin{array}{l}\text { MEKANIS } \\
\text { MEPKWT }\end{array}$} & \multirow[t]{2}{*}{$\begin{array}{l}\text { ATURAN } \\
\text { HUKUM }\end{array}$} & \multicolumn{2}{|c|}{$\begin{array}{c}\text { KONDISI (BERDASARKAN } \\
\text { WAKTU) }\end{array}$} \\
\hline & & PRA PUK GSPMII & $\begin{array}{l}\text { PASCA PUK } \\
\text { GSPMII }\end{array}$ \\
\hline $\begin{array}{l}\text { PERJANJIA } \\
\text { N KERJA } \\
\text { (PK) }\end{array}$ & Tertulis & $\begin{array}{ll}\text { - } & \text { PK untuk } \\
\text { pekerja } \\
\text { kontrak } \\
\text { perusaha } \\
\text { an hanya } \\
1 \text { rangkap } \\
\text { (pekerja } \\
\text { - Tidak ada } \\
\text { PK untuk } \\
\text { Pekerja } \\
\end{array}$ & $\begin{array}{l}\text { Setiap } \\
\text { hubungan } \\
\text { kerja diawali } \\
\text { dengan PK } \\
\text { dan Seluruh } \\
\text { pekerja } \\
\text { mendapatkan } \\
\text { salinan PK }\end{array}$ \\
\hline $\begin{array}{l}\text { JENIS } \\
\text { PEKERJAA } \\
\mathrm{N}\end{array}$ & $\begin{array}{l}\text { Tidak } \\
\text { boleh } \\
\text { di } \\
\text { pekerja } \\
\text { an } \\
\text { yang } \\
\text { bersifat } \\
\text { tetap } \\
\text { di } \\
\text { perusa } \\
\text { haan } \\
\text { (hanya } \\
\text { musima } \\
\text { n }\end{array}$ & Pekerja & $\begin{array}{l}\text { Masih sama } \\
\text { dengan } \\
\text { kondisi pra } \\
\text { berdirinya } \\
\text { PUK GSPMII } \\
\text { PT. } \\
\text { GCP, dimana } \\
\text { tidak ada } \\
\text { pekerja } \\
\text { PKWTT. } \\
\text { Pemisahan } \\
\text { hanya untuk } \\
\text { pekerja } \\
\text { kontrak yang } \\
\text { baru direkrut } \\
\text { perusahaan } \\
\text { guna } \\
\text { mengerjakan } \\
\text { pekerjaan yang } \\
\text { baru. }\end{array}$ \\
\hline $\begin{array}{l}\text { LAMANYA } \\
\text { PERJANJIA } \\
\text { NKERJA }\end{array}$ & $\begin{array}{l}\text { Untuk } \\
\text { berdas } \\
\text { arkan } \\
\text { waktu, } \\
\text { maksim } \\
\text { al } \\
\text { lamany } \\
\text { a } \\
\text { bekerja } \\
\text { adalah } \\
3 \\
\text { (tiga) } \\
\text { tahun } \\
\text { atau } 4 \\
\text { (empat } \\
\text { ) tahun }\end{array}$ & $\begin{array}{l}\text { Pekerja PKWT } \\
\text { bekerja tanpa } \\
\text { ada batasan } \\
\text { waktu, } \\
\text { Jika } \\
\text { perusahaan } \\
\text { tidak } \\
\text { membutuhka } \\
\text { n pekerja, } \\
\text { maka dengan } \\
\text { mudah di-PHK } \\
\text { tanpa adanya } \\
\text { kewajiban } \\
\text { apapun. }\end{array}$ & $\begin{array}{l}\text { Pekerja } \\
\text { perusahaan } \\
\text { ingin mem- } \\
\text { PHK pekerja } \\
\text { atau pekerja } \\
\text { ingin } \\
\text { mengundurka } \\
\mathrm{n} \text { diri, maka } \\
\text { hak pekerja } \\
\text { dipenuhi } \\
\text { ketenagakerjaa } \\
\mathrm{n} \text {. }\end{array}$ \\
\hline
\end{tabular}

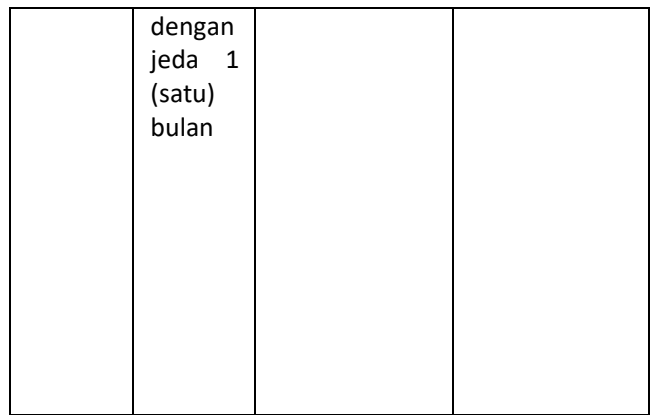

\subsection{Pemenuhan Norma Dan} Syarat Kerja PKWT Di PT. GCP. Sebelum berdirinya PUK GSPMII PT. GCP, norma kerja yang diberlakukan, khususnya bagi pekerja PKWT di PT. GCP sangat jauh dari aturan yang ada. Mulaidari upah yang diterima yang nilainya dibawah ketentuan yang berlaku, tidak terpenuhinya waktu kerja, kepesertaan dalam BPJS, hak berserikat yang tidak diakui perusahaan, sampai pada tidak diberikannya hak pesangon bagi pekerja yang ter- PHK. Kesemua ini merupakan bentuk diskriminasi atau perbedaan perlakuan pengusaha yang melihat pekerja berdasarkan status hubungan kerja.

Demikian pula dengan pelaksanaan syarat kerja bagi pekerja PKWT. Pekerja yang berstatus harian lepas tidak mendapatkan seragam kerja dari perusahaan, tidak mendapatkan fasilitas makan dan pengganti uang transport. Sementara bagi pekerja kontrak perusahaan, fasilitas makan yang didapat berbeda dengan pekerja PKWTT dalam menu dan porsinya.

Dengan berdirinya PUK GSPMII

PT. GCP, secara perlahan diskriminasi ini dapat dikurangi. Pekerja PKWT mendapatkan norma kerja sesuai dengan aturan yang berlaku. Mulai dari upah sesuai dengan SK Gubernur Jawa Barat termasuk dalam pembayran THR, kepesertaan BPJS yang menyeluruh, hak cuti 
yang berjalan, sampai pada hak pekerja wanita (Cuti Haid, melahirkan, keguguran dan kesempatan menyusui balita) yang dijalankan.

Kondisi kerja (Pelaksanaan Norma \& Syarat kerja) PKWT di PT. GCP (pra \& pasca berdirinya PUK GSPMII PT. GCP)

\begin{tabular}{|c|c|c|}
\hline \multirow[b]{2}{*}{$\begin{array}{l}\text { KONDISI } \\
\text { KERJA }\end{array}$} & \multicolumn{2}{|c|}{ MASA WAKTU } \\
\hline & $\begin{array}{l}\text { PRA PUK } \\
\text { GSPMII }\end{array}$ & $\begin{array}{l}\text { PASCA PUK } \\
\text { GSPMII }\end{array}$ \\
\hline UPAH & $\begin{array}{l}\text { Total Upah } \\
\text { Pekerja } \\
\text { harian Lepas } \\
\text { /bulannya } \\
\text { dibawah } \\
\text { UMK; Upah } \\
\text { pekerja } \\
\text { borongan } \\
\text { mengikuti } \\
\text { hasil kerja } \\
\text { yang } \\
\text { nominalnya } \\
\text { jaauh } \\
\text { dibawah } \\
\text { UMK yang } \\
\text { berlaku }\end{array}$ & $\begin{array}{l}\text { Mengikuti } \\
\text { UMK sesuai } \\
\text { Keputusan } \\
\text { Gubernur Jawa } \\
\text { Barat Tentang } \\
\text { UpahMinimum } \\
\text { Kabupaten/Kota } \\
\text { se Jawa barat }\end{array}$ \\
\hline $\begin{array}{l}\text { BPJS } \\
\text { Ketenagakerja } \\
\text { an } \\
\text { (JHT; JKK; } \\
\text { JKM) }\end{array}$ & $\begin{array}{l}\text { Pekerja } \\
\text { kontrak } \\
\text { hanya ikut } \\
\text { dalam } \\
\text { program JHT } \\
\text { dan JKK; } \\
\text { harian lepas } \\
\text { \& borongan } \\
\text { tidak diikut } \\
\text { sertakan }\end{array}$ & $\begin{array}{l}\text { Semua } \\
\text { pekerja } \\
\text { diikutsertaka } \\
\mathrm{n} \text { disemua } \\
\text { program } \\
\text { BPJS } \\
\text { Ketenagakerj } \\
\text { aan. }\end{array}$ \\
\hline $\begin{array}{l}\text { BPJS } \\
\text { Kesehatan }\end{array}$ & $\begin{array}{l}\text { Pekerja } \\
\text { kontrak } \\
\text { dianggap } \\
\text { lajang; } \\
\text { Pekerja } \\
\text { harian lepas } \\
\text { \& Borongan } \\
\text { tidak }\end{array}$ & $\begin{array}{l}\text { Semua pekerja \& } \\
\text { keluarganya } \\
\text { didaftarkan } \\
\text { sebagai peserta. }\end{array}$ \\
\hline $\begin{array}{l}\text { BPJS } \\
\text { Jaminan } \\
\text { Pensiun (JP) }\end{array}$ & $\begin{array}{l}\text { Tidak (belum } \\
\text { ada program } \\
\text { ini) }\end{array}$ & $\begin{array}{l}\text { Semua pekerja } \\
\text { diikutsertakan. }\end{array}$ \\
\hline
\end{tabular}

\begin{tabular}{|c|c|c|}
\hline $\begin{array}{l}\text { Makan } \\
\text { (perusahaan } \\
\text { menyediakan } \\
\text { kantin) }\end{array}$ & $\begin{array}{l}\text { Pekerja } \\
\text { mendapatkan }\end{array}$ & $\begin{array}{l}\text { Seluruh } \\
\text { pekerja } \\
\text { makan } \\
\text { dengan menu } \\
\text { dan porsi } \\
\text { yang sama. }\end{array}$ \\
\hline $\begin{array}{l}\text { Tunjangan } \\
\text { Transport }\end{array}$ & $\begin{array}{l}\text { Seluruh } \\
\text { pekerja } \\
\text { PKWT tidak } \\
\text { mendapatkan } \\
\text { tunjangan } \\
\text { transport }\end{array}$ & $\begin{array}{l}\text { Semua pekerja } \\
\text { mendapatkan } \\
\text { tunjangan } \\
\text { transport dengan } \\
\text { besaranyang } \\
\text { sama. }\end{array}$ \\
\hline $\begin{array}{l}\text { Istirahat } \\
\text { (Cuti) }\end{array}$ & $\begin{array}{l}\text { Seluruh } \\
\text { Pekerja } \\
\text { PKWT tidak } \\
\text { mendapatkan } \\
\text { Cuti; } \\
\text { demikian } \\
\text { juga cuti } \\
\text { haid, cuti } \\
\text { melahirkan } \\
\text { dan cuti } \\
\text { keguguran } \\
\text { bagi pekerja } \\
\text { PKWT } \\
\text { bergender } \\
\text { wanita }\end{array}$ & $\begin{array}{l}\text { Seluruh } \\
\text { yang sama. }\end{array}$ \\
\hline THR & \begin{tabular}{|l|} 
Pekerja \\
kontrak \\
mendapat \\
THR secara \\
proporsional \\
berdasarkan \\
PK terakhir; \\
Pekerja \\
harian lepas \\
dan \\
Borongan \\
\end{tabular} & Seluruh \\
\hline Waktu Kerja & $\begin{array}{l}\text { Jam kerja } \\
\text { Pekerja } \\
\text { harian lepas } \\
\& \text { borongan } \\
\text { melebihi } \\
\text { ketentuan; } \\
\text { bekerja } 12 \\
\text { jam } \\
\text { perharinya. } \\
\end{array}$ & 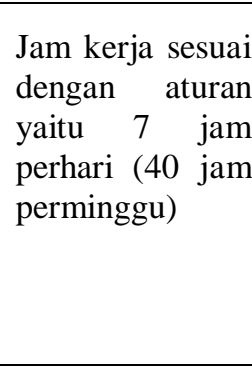 \\
\hline
\end{tabular}




\begin{tabular}{|c|c|c|}
\hline $\begin{array}{l}\text { Lembur \& } \\
\text { upahLembur }\end{array}$ & $\begin{array}{l}\text { Pekerja } \\
\text { harian lepas } \\
\& \text { borongan } \\
\text { tidak } \\
\text { mengenal } \\
\text { adanya } \\
\text { lembur \& } \\
\text { upah lembur }\end{array}$ & $\begin{array}{l}\text { Pekerja harian } \\
\text { lepas yang jam } \\
\text { kerjanya } \\
\text { melebihi aturan } \\
\text { dihitung lembur } \\
\text { tetapi } \\
\text { perhitungan } \\
\text { lembur } \\
\text { menggunakan } \\
\text { jam kerja } \\
\text { normal. Jika } \\
\text { kerja lembur di } \\
\text { hari libur, } \\
\text { dihitung } \\
\text { upah/hari. }\end{array}$ \\
\hline
\end{tabular}

Dari paparan diatas, dapat diketahui bahwa berdirinya PUK GSPMII PT. GCP telah menghadirkan beberapa perubahan tentang mekanisme Perjanjian Kerja untuk waktu tertentu. Keberadaan PUK GSPMII PT. GCP juga telah membuahkan perbaikan tentang pelaksanaan norma dan syarat kerja di perusahaan, khususnya bagi pekerja PKWT.

Akan tetapi, belum semua mekanisme pelaksanaan perjanjian kerja waktu tertentu (PKWT) dapat dilaksanakan di PT. Grafitecindo CiptaPrima walaupun ada jaminan keberlangsungan bekerja bagi pekerja waktu tertentu ataupun pekerja harian lepas di perusahaan. Adapun pelanggaran terhadap mekanisme pelaksanaan penggunaan pekerja waktu tertentu dan pelanggaran atas norma kerja yang masih terjadi di PT. Grafitecindo CiptaPrima, diantaranya:

1. Pekerja kontrak dan pekerja harian lepas di PT. Grafitecindo CiptaPrima melaksanakan pekerjaan yang terkategorikan sebagai pekerjaan tetap di perusahaan. Hal ini melanggar Pasal 59 ayat (1) Undang-undang No. 13 Tahun 2003 Tentang Ketenagakerjaan, dimana pelaksanaan PKWT haruslah meliputi pekerjaan yang meliputi:
a. Pekerjaan yang sekali selesai atau sementara sifatnya;
b. Pekerjan yang perkiraan penyelesaiannya tidak terlalu lama dan palinglama 3 (tiga) tahun;
c. Pekerjaan yang bersifat musiman; atau
d. Pekerjaan yang berhubungan dengan produk dan kegiatan baru atauproduk tambahan yang masih dalam masa percoban atau penjajakan.

Secara hukum, pelanggaran ini membuat hubungan kerja berubah menjadi Perjanjian Kerja Waktu Tidak Tertentu (PKWTT) atau pekerja menjadi pekerja tetap, sesuai dengan Pasal 59 ayat (7) UUK.

2. Masa kerja yang menyalahi aturan, baik bagi pekerja kontrak maupun pekerja harian lepas.

3. Perjanjian kerja untuk waktu tertentu (bagi pekerja kontrak) dan harian lepas yang berkepanjangan. Keadaan ini menimbulkan pekerja kehilangan semangat (motivasi) dalam bekerja karena status kerja mereka yang stagnan dalam waktu yang lama.

4. Dikarenakan status Pekerja harian lepas, maka tidak mengenal adanya upah lembur jika pekerja tersebut bekerja di hari libur, baik hari minggu ataupun hari libur nasional.

\section{Langkah PUK-GSPMII PT. GCP Dalam Melindungi Pekerja Waktu Tertentu Di PT.GCP. 2.1 Sejarah PUK-GSPMII PT. GCP.}

PT. Grafitecindo CiptaPrima (PT. GCP) merupakan sebuah perusahaan yang beralamat di Kawasan Industri Jababeka V Blok U Kav. 92-93 Cikarang Kabupaten Bekasi Jawa Barat, berdiri pada 10 
November 1993. PT. GCP bergerak di bidang packaging (kemasan) yang mengerjakan kemasan (packaging) susu formula dari Nestle dan SGM, kemasan minuman kotak dari PT. Mayora Indah Tbk, serta mengerjakan pesanan dari Hallmark dan Target, perusahaan yang berada di Amerika Serikat.

Pada 23 Juni 2008, pekerja di PT. GCP secara resmi bergabung dengan Gabungan Serikat Pekerja Manufaktur Independen Indonesia (GSPMII), sesuai dengan Surat Pencatatan Serikat Pekerja oleh Dinas Tenaga Kerja Kabupaten Bekasi dengan Nomor Pencatatan 736/CTT.250/VI/2008. Adapun alasan dasar pekerja bergabung dengan serikat pekerja adalah:

1. Sistem hubungan kerja waktu tertentu dalam perusahaan yang melanggar mekanisme pelaksanaan perjanjian kerja waktu tertentu (PKWT) yang sangat merugikan pekerja, dimana terdapat pekerja kontrak, pekerja yayasan (outsourching), pekerja harian lepas, bahkan pekerja borongan.

2. Tidak adanya jaminan keberlangsungan bekerja pekerja waktu tertentu di perusahaan dimana sangat mudah bagi pengusaha (manajemen) untuk memutus hubungan kerja pekerja tanpa mengindahkan prosedur yang berlaku dan tanpa memberikan hak pekerja berupa pesangon.

3. Buruknya sistem kepemimpinan di perusahaan, dimana sikap dan perlakuan atasan ke bawahan atau dari manajemen ke pekerja jauh dari level manusiawi.

4. Sulitnya pekerja tetap yang terPHK mendapatkan hak pesangon.

5. Tidak dilaksanakannya norma kerja yang berlaku seperti upah pokok bagi pekerja harian lepas yang dibawah Upah Minimum
Kabupaten Bekasi, tidak adanya antar jemput ataupun uang transport sebagai pengganti, tidak adanya fasilitas makan ataupun uang makan bagi pekerja, tidak maksimalnya kepesertaan di Badan Penyelenggara Jaminan Sosial (BPJS) baik secara program yang ada maupun tidak seluruh pekerja yang didaftarkkan.

6. Tidak dilaksanakannya syarat kerja sebagaimana yang termuat dalam Perjanjian Kerja atau Peraturan Perusahaan (waktu itu).

7. Penilaian kerja yang lebih mengedepankan faktor Subyektif dari pemangku kepentingan (atasan).

Pekerja di PT. GCP memilih GSPMII menjadi wadah perjuangannya dikarenakan dari sekian banyak serikat pekerja yang ada di regional Kabupaten Bekasi, hanya GSPMII yang mau menerima keberadaan pekerja dengan perjanjian kerja waktu tertentu (kontrak) sebagai anggotanya dan siap membela hak pekerja tersebut, termasuk membela keberlangsungan bekerja bagi pekerja kontrak. Hal ini menjadi pertimbangan yang utama karena permasalahan pekerja kontrak ini merupakan salah satu hal yang dianggap "kritikal" oleh pekerja PT. GCP, mengingat status hubungan kerja kontrak yang variatif dan besarnya jumlah pekerja kontrak. Banyak hal yang harus diluruskan dalam pelaksanaan dan perbaikan kondisi kerja (norma dan syarat kerja) bagi PKWT. Saat pembentukan GSPMII di PT. GCP, jumlah pekerja keseluruhan kurang lebih 1000 (seribu) orang pekerja. Dari total pekerja tersebut, jumlah pekerja berstatus kontrak baik kontrak berdasarkan waktu, Outsourching, pekerja harian lepas maupun pekerja borongan mencapai 850 (delapan ratus lima puluh) orang pekerja atau mencapai $85 \%$ dari total keseluruhan pekerja yang ada. Sementara, pekerja yang 
bergabung dengan GSPMII diawal pendiriannya berjumlah hanya di kisaran 100 (seratus) pekerja, dengan komposisi 45 (empat puluh lima) pekerja tetap sebagai inisiator pendiri dan 55 (lima puluh lima) pekerja kontrak, yang berbentuk PKWT atas dasar waktu perjanjian dan pekerja harian lepas.

Pimpinan Unit Kerja (PUK) adalah satuan unit dari organisasi serikat pekerja yang ada di tingkat perusahaan. Pengurus Pimpinan Unit Kerja ini adalah pekerja di perusahaan tersebut yang dipilih oleh anggota melalui mekanisme pemilihan. Karena pekerja di PT. GCP telah bergabung dengan serikat pekerja yang bernama Gabungan Serikat Pekerja Manufaktur Independen Indonesia (GSPMII), maka unit kerja di PT. GCP disebut dengan Pimpinan Unit Kerja Gabungan Serikat Pekerja Manufaktur Independen Indonesia (PUK GSPMII) PT. GCP.

Hadirnya GSPMII di PT. GCP mendapat penolakan dari pengusaha. Penolakan pengusaha dan manajemen pertama berupa tidak merespon keinginan serikat pekerja untuk memperkenalkan diri (Audiensi) walaupun pihak serikat pekerja sudah mengirimkan surat permohonan Audiensi. Selanjutnya, pengusaha (melalui manajemen) melakukan tindakan kampanye anti serikat pekerja dengan membentuk serikat pekerja tandingan berupa Serikat Pekerja Tingkat Perusahaan (SPTP) serta melakukan mutasi terhadap 6 (enam) pekerja yang semulanya bekerja dibagian produksi ke bagian General Affair (GA) dan demosi kepada hampir 30 (tiga puluh) pekerja yang semula menjabat sebagai operator di beberapa bagian produksi menjadi Helper (pembantu). Kesemua pekerja yang mendapat perintah mutasi dan demosi merupakan pengurus dan anggota aktif di PUK GSPMII PT. GCP.

Pimpinan Unit Kerja Gabungan Serikat Pekerja Manufaktur Independen Indonesia
(PUK GSPMII) PT. GCP tidak mengambil tindakan balasan atas penolakan pengusaha walaupun langkah pengusaha termasuk dalam tindakan yang mengarah pada pemberangusan serikat pekerja sebagaimana yang terdapat dalam Pasal 28 Undang-undang Nomor 21 Tahun 2000 Tentang Serikat Pekerja /Serikat Buruh. PUK GSPMII PT. GCP lebih memfokuskan diri pada tujuan awal, yaitu pemenuhan norma dan syarat kerja bagi seluruh pekerja di perusahaan. Pelanggaran terhadap norma dan syarat kerja menjadi prioritas bagi pengurus PUK.

Saat ini PT. GCP memiliki pekerja sebanyak kurang lebih 900 (sembilan ratus) orang pekerja, dengan pekerja kontrak mencapai 700 (tujuh ratus) orang pekerja. Dari Pekerja kontrak saat ini, sebanyak 200 (dua ratus) orang pekerja merupakan pekerja baru yang direkrut untuk memenuhi pesanan konsumen baru, dalam hal ini adalah PT. Fontera (perusahaan pengepakan susu formula Nestle dan Dancow) dan pesanan dari Hallmark dan Target. Sementara pekerja yang tercatat menjadi anggota Pimpinan Unit Kerja Gabungan Serikat Pekerja Manufaktur Independen Indonesia (PUK GSPMII) PT. GCP sejumlah 712 (tujuh ratus dua belas) orang pekerja yang terdiri dari 161 (seratus enam puluh satu) orang pekerja berstatus permanen atau karyawan tetap, 219 (dua ratus sembilan belas) orang pekerja kontrak dan 332 (tiga ratus tiga puluh dua) pekerja harian lepas. 26 Terhadap pekerja kontrak dan harian lepas ini, hak normative dan syarat kerja telah sesuai dengan Perjanjian Kerja (PK) dan Perjanjian Kerja Bersama (PKB). Selain itu, mereka juga mendapatkan jaminan keberlangsungan bekerja dari perusahaan. Jaminan ini tidak terlepas dari peran serikat pekerja yang ada, yakni Pimpinan Unit Kerja Gabungan Serikat Pekerja Manufaktur Independen Indonesia (PUK GSPMII) PT. GCP. Sementara 
untuk pekerja kontrak yang bukan anggota PUK GSPMII PT. GCP, sebanyak 200 (dua ratus) orang pekerja baru yang direkrut oleh perusahaan dikarenakan tingginya kontrak rekanan yang harus diselesaikan. Kepada mereka yang dalam hal ini (200 pekerja baru) hanya mendapatkan hak-hak normatif dan syarat kerja sesuai dengan aturan dan PK (PKB) tetapi tidak mendapatkan jaminan keberlangsungan bekerja. Saat pekerjaan (order) perusahaan turun, mereka diputus hubungan kerjanya. 27

\footnotetext{
26 Data anggota Pimpinan Unit Kerja Gabungan Serikat Pekerja manufaktur Independen Indonesia (PUK GSPMII) PT. Grafitecindo CiptaPrima (GCP) di Bulan November 2019.

${ }^{27}$ Wawancara dengan Suherman, Op. Cit.
}

\section{$2.2 \quad$ Langkah PUK-GSPMII PT. Graftecindo Cipta Prima (GCP) Dalam Menyelesaikan Permasalahan Pekerja Kontrak.}

Permasalahan ketenagakerjaan yang dihadapi oleh PUK GSPMII PT. GCP di awal terpentuknya adalah banyaknya tenaga kerja PKWT dimana mekanisme pelaksanaan tidak sesuai dengan peraturan perundang-undangan yang berlaku serta tidak terpenuhinya hak pekerja, baik yang berupa normatif maupun syarat kerja sebagaimana yang termuat dalam Perjanjian Kerja (PK) dan Peraturan Perusahaan (PP). Aturan ketenagakerjaan secara tegas menyatakan bahwa mekanisme pelaksanaan PKWT harus dipatuhi dengan konsekwensi berubahnya status hubungan kerja menjadi PKWTT dan norma kerja serta syarat kerja tidak boleh lebih rendah dari ketentuan yang berlaku. Namun dalam pelaksanaannya, banyak perusahaan tidak memahami dan melaksanakan dengan sungguh-sungguh aturan tersebut, termasuk di PT. GCP.

Langkah yang dilakukan PUK GSPMII PT. GCP terhadap tidak berjalannya mekanisme PKWTT dan tidak dipenuhinya norma dan syarat kerja adalah dengan sesegera mungkin mengirimkan surat Permohonan Bipartite kepada Pengusaha (Manajemen) untuk menyelesaikan permasalahan ini. Langkah yang ditempuh pengurus PUK ini mendapat tantangan dari pengusaha melalui manajemennya berupa intimidasi kepada pengurus dan anggota aktif organisasi semakin gencar dilakukan. Intimidasi yang sangat terasa adalah perlakuan diskriminatif dalam pemberian kerja lembur dimana anggota serikat pekerja tidak diperbolehkan untuk lembur.

Akhirnya pada pertengahan tahun 2009 terjadi perubahan sikap dan perlakuan pengusaha atas serikat pekerja mulai sedikit terlihat. Hal ini tidak terlepas dari kejadian di PT. Printec Perkasa II, sebuah perusahaan yang masih bernaung dalam group yang sama dengan PT. GCP, yang serikat pekerjanya sama yaitu GSPMII dan berada di Kabupaten Bekasi juga. Pengusaha mengajak Pengurus PUK GSPMII baik yang berada di PT. PP2 maupun di PT. GCP untuk bermusyawarah. Akhirnya musyawarah menghasilkan kesepakatan:

- Pengusaha menerima dan mengakui keberadaan Pimpinan Unit Kerja Gabungan Serikat Pekerja Manufaktur Independen Indonesia (PUKGSPMII) di kedua perusahaan.

- Pengusaha menjamin keberlangsungan bekerja di perusahaan, termasuk bagi pekerja yang berstatus kontrak dan harian lepas di PT. GCP.

- Perusahaan akan melakukan perubahan status pekerja kontrak dan harian lepas. Sementara untuk jenis pekerja borongan dihilangkan dan pekerja borongan akan menjadi pekerja harian lepas. Adapun mekanisme perubahan status 
pekerja akan dilakukan secara bertahap mengingat besarnya jumlah pekerja kontrak dan pekerja harian lepas.

- Perusahaan akan membenahi norma dan syarat kerja, dimulai dengan pembenahan upah pokok dan jam kerja bagi pekerja harian lepas.

- Untuk norma dan syarat kerja lainnya, manajemen akan berkoordinasi dengan Pimpinan Unit Kerja Gabungan Serikat Pekerja Manufaktur Independen Indonesia (PUKGSPMII) PT. GCP dalam waktu secepatnya.

Kesepakatan ini menjadi pembeda cara perjuangan Pimpinan Unit Kerja Gabungan Serikat Pekerja Manufaktur Independen Indonesia (PUK-GSPMII) PT. GCP. Jika di serikat pekerja lain atau di perusahaan lain, dimana pelanggaran terhadap mekanisme PKWT tidak menjadi prioritas dalam pembelaan serikat pekerja. Kondisi ini dibuktikan dimana mayoritas perusahaan yang ada dimana didalamnya terdapat serikat pekerja, keberadaan pekerja kontrak seolah-olah dibiarkan. Sangat mudah ditemukan pekerja kontrak yang berakhir hubungan kerjanya tanpa ada pembelaan dari serikat pekerja, sementara mekanisme pelaksanaan PKWT melanggar aturan yang ada. Demikian pula terhadap pemenuhan norma dan syarat kerja. Sangat banyak pekerja kontrak disatu perusahaan dimana norma dan syarat kerja yang didapatnya, dibawah norma dan syarat kerja yang tertulis di Perjanjian Kerja (PK) atau Perjanjian Kerja Bersama (PKB). Hal ini membuat serikat pekerja yang seharusnya berfungsi sebagai wadah mendorong terjadinya perubahan status sosial pada masyarakat menjadi tidak berjalan, dengan kata lain bahwa serikat pekerja tidak mampu menjadi agen perubahan. 28

Selain kondisi diatas, ada pula serikat pekerja dalam mengawal mekanisme pelaksanaan PKWT di perusahaannya bersikeras melaksanakan aturan hukum yang berlaku secara kaku dengan mendesak perusahaan mengeluarkan Surat Pengangkatan (SK) perubahan status dari PKWT menjadi PKWTT kepada seluruh pekerja kontrak yang ada di perusahaan sehingga menimbulkan gesekan yang cukup keras dengan pengusaha yang mengakibatkan buruknya tatanan komunikasi antara pekerja (serikat pekerja) dengan pengusaha (Manajemen) sehingga menimbulkan ketidak nyamanan baik bagi pekerja dalam bekerja maupun bagi pengusaha dalam menjalankan perusahaannya. 29

Walau dalam aturan ketenagakerjaan menyatakan bahwa sanksi atas pelanggaran mekanisme pelaksanaan PKWT adalah berubahnya status kerja menjadi PKWTT (pekerja tetap), tetapi PUK GSPMII PT. GCP tidak menuntut agar pengusaha untuk mengeluarkan Surat Keterangan (SK) karyawan tetap untuk seluruh pekerja kontrak. Hal ini dikarenakan sangat besarnya jumlah pekerja yang berstatus PKWT dengan bermacam bentuknya di perusahaan. PUK GSPMII PT. GCP dapat memahami bahwa pola pikir pengusaha yang sangat keberatan jika diharuskan mengeluarkan Surat Pengangkatan dalam jumlah yang besar dalam satu waktu. Terlebih lagi tingkat pendidikan mayoritas pekerja PT. GCP khususnya pekerja PKWT berbentuk Harian lepas dan Borongan yang sangat minim menjadi satu pertimbangan PUK jika harus menempuh jalur hukum yang dapat berakibat mayoritas pekerja ter-PHK sehingga akan kesulitan jika harus mencari lapangan pekerjaan di tempat lain walaupun bagi pekerja tersebut ada kemungkina mendapatkan kompensasi berupa sejumlah nominal dalam bentuk pesangon. 30

PUK GSPMII PT. GCP lebih 
mengutamakan pemenuhan norma dan syarat kerja bagi seluruh pekerja dan jaminan keberlangsungan bekerja bagi pekerja kontrak di perusahaan yang tercatat sebagai anggotanya. Adapun PUK berpandangan bahwa pemenuhan norma dan syarat kerja serta jaminan keberlangsungan bekerja jauh lebih penting jika dibandingkan dengan secarik kertas yang berisikan pengangkatan menjadi PKWTT. 31.

\footnotetext{
${ }^{30}$ Wawancara dengan Suherman, Op. Cit.

${ }^{28}$ Wawancara dengan Meryanto SH, Ketua

Bidang II PUK GSPMII PT. Printec Perkasa

II Periode 2012-2021 (eks Sekretaris Umum PUK GSPMII PT. PP2 Periode 2008-2012; eks Team Rekruitment \& Pengembangan Organisasi DPP GSPMII) di Sekretariat PUK GSPMII PT. Printec Perkasa II Tanggal 7 September 2020.

${ }^{29}$ Ibid.

${ }^{31}$ Ibid.
}

\subsection{Kondisi Pekerja PKWT saat Ini Di PT. GCP.}

Pelaksanaan mekanisme pekerja waktu tertentu di PT. GCP sarat dengan pelanggaran-pelanggaran terhadap Undang Undang Ketenagakerjaan (UUK), baik tentang perjanjian kerjanya (Pasal 57 ayat (2), jenis pekerjaannya (pasal 59 ayat (1) dan ayat (2)), lamanya perjanjian kerja (Pasal 59 ayat (3) dan (4), dan (6)), tentang norma kerja (BAB X) maupun sarat kerja sebagaimana yang terdapat dalam Perjanjian Kerja (PK), atau Perjanjian Kerja Bersama (PKB) yang berlaku di perusahaan. Kondisi ini memberikan tantangan kepada pengurus serikat pekerja yang ada, dalam hal ini Pimpinan Unit Kerja Gabungan Serikat Pekerja Manufaktur Independen Indonesia (PUK GSPMII) PT. GCP untuk memperbaiki kondisi hubungan kerja yang ada.

Setelah melalui perjuangan yang panjang maka hubungan kerja yang berlaku di PT. GCP telah mengalami perubahan. Hubungan kerja berdasarkan perjanjian keja waktu tertentu (PKWT) antara pekerja dengan pengusaha di PT. GCP saat ini sudah jauh lebih baik dibandingkan dengan masa sebelum adanya serikat pekerja Gabungan Serikat Pekerja Manufaktur Independen Indonesia (GSPMII) walaupun secara aturan yang berlaku masih belum sempurna. Hubungan kerja untuk waktu tertentu yang ada di PT. GCP saat ini sudah tidak mengenal adanya pekerja outsourching (pekerja dari perusahaan penyedia jasa pekerja), harian lepas ataupun pekerja borongan.

Pekerja yang dahulunya berstatus pekerja outsourching, harian lepas dan borongan kesemuanya diikat dengan perjanjian kerja untuk waktu tertentu, dengan jaminan (garansi) dari perusahaan bahwa hubungan kerja mereka tidak akan diputus dikarenakan habisnya masa waktu perjanjian kerja. Jika perusahaan memutus hubungan kerja, maka perusahaan harus mengeluarkan hak-hak pekerja yang diputus hubungan kerjanya sesuai dengan aturan yang berlaku dalam bentuk pemberian pesangon dan uang penghargaan masa kerja yang terhitung dari awal pekerja bekerja di perusahaan serta uang penggantian hak.

Hak-hak pekerja kontrak inipun disamakan dengan hak yang didapatkan pekerja dengan perjanjian kerja untuk waktu tidak tertentu (PKWTT) atau pekerja tetap. Mereka berhak mendapatkan cuti tahunan, mendapat Tunjangan Hari Raya (THR) dan tunjangan-tunjangan lainnya. Bagi pekerja wanita yang berstatus kontrak berhak atas cuti haid, cuti melahirkan atau keguguran dengan tetap mendapat upah, serta kemudahan dalam menyusui bayinya. Jika pekerja wanita yang saat cuti melahirkan ternyata memasuki berakhirnya masa kontrak, maka pekerja yang bersangkutan datang ke perusahaan untuk menandatangani perpanjangan perjanjian kerja. 
Dalam pemenuhan sarat kerja, kehadiran PUK GSPMII PT. GCP juga membawa perubahan. Seluruh pekerja kontrak mendapatkan perlakuan yang sama dengan pekerja tetap, seperti dalam pemberian seragam kerja, fasilitas makan dan transport. Adapun beberapa sarat kerja diatur dalam Perjanjian Kerja Bersama PT. GCP berupa:

a) Persamaan perlakuan bagi seluruh pekerja dimana dalam mukadimah Perjanjian Kerja Bersama (PKB) antara PT. Grafitecindo CiptaPrima (PT. GCP) dengan PUK GSPMII PT. GCP dinyatakan:

"Adalah menjadi prinsip dan kewajiban semua pihak sebagai manusia tanpa memandang perbedaan agama, suku bangsa dan jenis kelamin serta diberi kesempatan untuk maju dan meningkatkan kecakapan, keterampilan kerja sehingga daya kreatifitas yang dimiliki dapat dikembangkan dalam rangka mempertinggi produktivitas kerja demi kemajuan usaha dan peningkatan kesejahteraan pekerja dan keluarganya."

Kalimat diatas diaplikasikan di dalam pasal-pasal yang dibuktikan dengan tidak adanya perbedaan bagi pekerja dengan menggunakan kata "setiap pekerja", "Pekerja", atau "seluruh pekerja" dalam hal-hal yang berhubungan dengan norma (yang diperkuat dalam PKB) dan syarat kerja.

Dalam pelaksanaan di PT. GCP, kesemua norma kerja dan syarat kerja diatas berlaku bagi seluruh karyawan termasuk karyawan kontrak dan pekerja harian lepas. Melihat kondisi hubungan kerja waktu tertentu di PT. GCP saat ini, dapat diambil satu kesimpulan bahwa serikat pekerja yang ada, yaitu Pimpinan Unit Kerja Gabungan Serikat Pekerja Manufaktur Independen Indonesia (PUK GSPMII) PT. GCP telah mampu mengawal pelaksanaan hak bagi pekerja dengan perjanjian kerja waktu tertentu di perusahaan. Adapun hasil pengawalan tersebut dalam bentuk:

a. Syarat kerja yang didapat pekerja kontrak sesuai dengan aturan yang berlaku, dimana pekerja mendapatkan hak-hak normatifnya seperti upah yang sesuai, hak istirahat berupa hak cuti, tunjangantunjangan yang merupakan bentuk peningkatan kesejahteraan pekerja seperti tunjangan makan, tunjangan transport, dan Tunjangan Hari Raya (THR).

b. Pekerja kontrak mendapatkan jaminan keberlangsungan bekerja di perusahaan sehingga tidak ditakutkan lagi dengan ancaman pemutusan hubungan kerja yang semena-mena. Jikapun terjadi pemutusan hubungan kerja, maka pekerja mendapatkan hak pesangon sebagaimana ketentuanyang berlaku dengan penghitungan masa kerja dihitung dari awal bekerja di perusahaan.

\subsection{Strategi PUK GSPMII PT. GCP Dalam Melindungi Pekerja PKWT Dilihat Dari Perspektif Tujuan Hukum. \\ PUK GSPMII PT. GCP lebih} mengutamakan pemenuhan syarat kerja dan norma kerja yang berorientasi kepada didapatnya jaminan keberlangsungan bekerja bagi pekerja kontrak dibandingkan dengan penegakan akibat hukum dari pelanggaran mekanisme PKWT.

Sangat jelas dalam undang-undang Nomor 13 Tahun 2003 Tentang Ketenagakerjaan bahwa pelanggaran atas mekanisme perjanjian kerja untuk waktu tertentu berakibat pada berubahnya status hubungan kerja menjadi Perjanjian Kerja untuk Waktu Tidak tertentu (PKWTT), seperti:

1. Pasal 57 ayat (2) yang intinya mengatur bahwa Perjanjian kerja untuk waktu tertentu yang dibuat tidak tertulis 
dinyatakan sebagai perjanjian kerja untuk waktu tidak tertentu.

2. Pasal 63 ayat (1) yang menyatakan "Dalam hal perjanjian kerja waktu tidak tertentu dibuat secara lisan, maka pengusaha wajib membuat surat pengangkatan bagi pekerja/buruh yang bersangkutan."

3. Pasal 59 ayat (7) yang menyatakan bahwa "Perjanjian kerja untuk waktu tertentu yang tidak memenuhi ketentuan pasal ini maka demi hukum menjadi perjanjian kerja waktu tidak tertentu."

Dari ketiga Pasal diatas sangat jelas bahwa pelanggaran atas mekanisme PKWT berakibat berubahnya hubungan kerja pekerja. Jika kita lihat hubungan kerja yang terjadi di PT. GCP, maka berdasarkan aturan diatas maka hubungan pekerja harus menjadi PKWTT. Akan tetapi, PUK GSPMII PT. GCP lebih memilih cara lain, yaitu perbaikan kondisi kerja berupa pemenuhan norma dan syarat kerja serta jaminan keberlangsungan bekerja bagi mayoritas pekerja.

Jika kita mengacu pada Undangundang Nomor 13 Tahun 2003 Tentang Ketenagakerjaan, terbaca bahwa tujuan pembangunan ketenagakerjaan yaitu memberdayakan dan mendayagunakan tenaga kerja secara optimal dan manusiawi, mewujudkan pemerataan kesempatan kerja dan penyediaan tenaga kerja yang sesuai dengan kebutuhan pembangunan nasional dan daerah, memberikan perlindungan kepada tenaga kerja dalam mewujudkan kesejahteraan, dan meningkatkan kesejahteraan tenaga kerja dan keluarganya. 32

Dari 4 (empat) tujuan pembangunan nasional, 3 (tiga) tujuannya adalah untuk menjaga hak dan kepentingan pekerja atau buruh. Sedangkan 1 (satu) tujuan untuk menciptakan pemerataan kesempatan kerja (penyerapan tenaga kerja). Dengan kata lain, menjaga keberlangsungan operasional perusahaan sehingga dapat menyerap tenaga kerja. Tujuan pembangunan ketenagakerjaan tersebut merupakan tanggungjawab semua pihak yang terlibat didalamnya, mulai dari pemerintah, pengusaha dan asosiasi pengusaha maupun pekerja dan serikat pekerja.

Jika dilihat kolerasi antara langkah (strategi) PUK GSPMII PT. GCP dengan tujuan pembangunan ketenagakerjaan berdasarkan UUK diatas, maka PUK GSPMII PT. GCP telah dapat menjaga agar tujuan pembangunan ketenagakerjaan tersebut, khususnya di PT. GCP, dimana hak dan kepentingan pekerja atau buruh dapat diijaga dan perusahaan dapat beroperasi dengan lancar. ${ }^{33}$

Dalam menegakkan hukum, ada tiga unsur yang harus diperhatikan, yaitu kepastian hukum, kemanfaatan dan keadilan. Ketiga unsur tersebut harus mendapat perhatian secara proporsional seimbang. Tetapi dalam praktek tidak selalu mudah mengusahakan kompromi secara proporsional seimbang antara ketiga unsur tersebut. Tanpa kepastian hukum orang tidak tahu apa yang harus diperbuatnya dan akhirnya timbul keresahan. Tetapi terlalu menitikberatkan pada kepastian hukum, terlalu ketat mentaati peraturan hukum akibatnya kaku dan akan menimbulkan rasa tidak adil. 34

Kepastian hukum merupakan harapan bagi pencari keadilan. Dengan adanya kepastian hukum, masyarakat akan tahu kejelasan akan hak dan kewajiban menurut hukum. Kepastian hukum ini dapat diwujudkan melalui aturan yang baik dan jelas dalam suatu undang-undang dan akan jelas pula penerapannya. Dengan kata lain kepastian hukum itu berarti tepat hukumnya, subjeknya dan objeknya serta 
ancaman hukumannya. Keadilan merupakan salah satu tujuan hukum yang paling banyak dibicarakan sepanjang perjalanan sejarah filsafat hukum. Tujuan hukum bukan hanya keadilan, tetapi juga kepastian hukum dan kemanfaatan hukum. Idealnya, hukum memang harus mengakomodasikan ketiganya. Pengertian keadilan adalah keseimbangan antara yang patut diperoleh pihak-pihak, baik berupa keuntungan maupun berupa kerugian. Membicarakan keadilan tidak semuda yang kita bayangkan, karena keadilan bisa bersifat subjektif dan bisa individualistis.

\footnotetext{
rasjuddin.blogspot.com hubungan 3 tujuan hukum, http://rasjudin.blogspot.com, disadur padatanggal 27 Agustus 2020 Pukul 20.00 WIB.

${ }^{35}$ Ibid.
}

Kemanfaatan hukum perlu diperhatikan karena semua orang mengharapkan adanya manfaat dalam pelaksanaan penegakan hukum. Jangan sampai penegakan hukum justru menimbulkan keresahan masyarakat. Jika dikaitkan dengan kenyataan, sering sekali antara kepastian hukum terjadi benturan dengan kemanfaatan, atau antara keadilan dengan kepastian hukum, antara keadilan terjadi benturan dengan kemanfaatan. 35 Salah satu contohnya adalah yang dihadapi oleh PUK GSPMII PT. GCP dalam permasalahan pekerja PKWT.

Seyogyanya ketiga nilai dasar hukum itu dapat diwujudkan secara bersamasama, tetapi manakala tidak mungkin, maka haruslah diprioritaskan keadilan, kemanfaatan dan kepastian hukum. Dalam prakteknya, penegakan hukum dapat terjadi dilematik yang saling berbenturan antara ketiga unsur tujuan hukum diatas, dimana dengan pengutamaan " kepastian hukum " maka ada kemungkinan unsurunsur lain diabaikan atau dikorbankan. Demikian juga jika unsur "kemanfaatan" lebih diutamakan, maka kepastian hukum dan keadilan dapat dikorbankan. 36

Dalam kajian Ilmu Hukum, terdapat teori pengayoman, yang menyatakan bahwa tujuan hukum adalah untuk mengayomi manusia, baik secara aktif maupun pasif. Secara aktif yakni upaya menciptakan suatu kondisi kemasyarakatan yang manusiawi dalam proses yang berlangsung secara wajar, sedangkan secara pasif adalah mengupayakan pencegahan atas tindakan yang sewenang-wenang dan penyalahgunaan hak. Memang teori tersebut tampak berusaha menggabungkan kelemahan-kelemahan terhadap keadilan hukum dan kepastian hukum. Teori Pengayoman dalam pandangan secara aktif, menunjukkan pada suatu teori kemanfaatan hukum; sementara dalam pandangan secara pasif, menunjukkan pada suatu teori keadilan hukum.

Menurut Achmad Ali, bahwa aliran etis dapat dianggap sebagai ajaran moral ideal, atau ajaran moral teoretis; sebaliknya ada aliran yang dapat dimasukkan dalam ajaran moral praktis, yaitu aliran utilitas. Penganut aliran utilitas ini menganggap, bahwa tujuan hukum semata-mata untuk memberikan kemanfaatan atau kebahagiaan yang sebesar-besarnya bagi sebanyak-banyaknya warga masyarakat. Penanganannya didasarkan pada filsafat sosial, bahwa setiap warga masyarakat mencari kebahagiaan, dan hukum merupakan salah satu alatnya. 37

Jika melihat pada unsur penegakan hukum, maka langkah yang mendasari PUK GSPMII PT. GCP dalam menyelesaikan permasalahan pekerja waktu tertentu (PKWT) di perusahaan adalah berpatokan pada asas kemanfaatan dibandingkan asas kepastian hukum dan keadilan, dengan berlandaskan pada manfaat yang didapat bagi pekerja, serikat pekerja dan pengusaha.

\footnotetext{
${ }^{36}$ Ibid.

${ }^{37}$ metrokaltara.com kemanfaatan hukum
} 
https://www.mertokaltara.com disadur pada tanggal 27Agustus 2020 Pukul 20.40 WIB.

\section{KESIMPULAN}

Berdasakan hasil penelitian dan pembahasan diatas, maka dapat disimpulkan sebagaiberikut:

1. Perjanjian kerja waktu tertentu (PKWT) dapat berbentuk pekerja kontrak masa waktu, Pekerja Harian dan Pekerja Outsourching. Terhadap pekerja PKWT, terdapat norma dan syarat kerja yang harus dipenuhi pengusaha. Selain itu, ada juga mekanisme Perjanjian kerja waktu tertentu (PKWT) yang jika dilanggar oleh pengusaha akan berdampak pada berubahnya hubungan kerja dari Perjanjian kerja waktu tertentu (PKWT) menjadi Perjanjian kerja waktu tidak tertentu (PKWTT) sebagaimana yang dimaksud dalam Pasal 65 Undang-undang Nomor 13 Tahun 2003 Tentang Ketenagakerjaan.

2. PUK GSPMII PT. GCP belum mampu mengawal mekanisme pelaksanaan PKWT sebagaimana aturan ketenagakerjaan yang berlaku, tetapi mampu mengawal pemenuhan norma dan syarat kerja di perusahaan.

3. Walaupun PUK GSPMII PT. GCP belum mampu mengawal mekanisme pelaksanaan PKWT sebagaimana aturan ketenagakerjaan yang berlaku, namun hal ini tidak terlepas dari strategi PUK GSPMII yang lebih mengutamakan asas kemanfaatan hukum dibandingkan dengan kepastian hukum. Hal ini didasari oleh beberapa hal, diantaranya tingkat pendidikan yang rendah dari pekerja PKWT di perusahaan dan besarnya manfaat yang diterima pekerja PKWT di PT. GCP.

\section{E. Daftar Pustaka \\ Buku}

Agusmidah dkk. Bab-BabTentang Hukum Perburuhan Indonesia. Denpasar: Pustaka Larasan, 2012

Djumadi. Hukum Perburuhan Perjanjian Kerja. Jakarta: Raja GrafindoPersada, 1999

Khakim, Abdul. Dasar-Dasar Hukum Ketenagakerjaan Indonesia, Cet.4, Bandung: Citra Aditya bakti, 2014.

Rusli, Hardijan. Hukum ketenagakerjaan, Jakarta: Ghalia Indonesia, 2004

Suteja, Adrian. Hukum Perburuhan, Jakarta: Sinar Grafika, 2009

Suwanto, Hubungan Industrial Dalam praktek, Cet. 1 Jakarta: AHII, 2003

Syamsuddin, Mohd. Syaufii. PerjanjianPerjanjian Dalam Hubungan Industrial. Jakarta: Sarana Bhakti Persada, 2005

Zaeni, Asyhadie. Hukum Kerja Hukum Ketenagakerjaan Bidang Hubungan Kerja, Jakarta: Raja Grafindo Persada, 2013

\section{Peraturan Perundang-undangan}

Undang-undang Nomor 13 Tahun 2003 Tentang Ketenagakerjaan.

Keputusan Menteri Tenaga Kerja dan Transmigrasi Nomor 100 Tahun 2004 Tentang Ketentuan Pelaksanaan Perjanjian Kerja Waktu Tertentu.

\section{Internet}

Jurnal Hukum Perdata Univ. Gadjah Mada Vol. 2, No. 2, November 2013

idtesis.com metode penelitian hukum empiris dan normatif, https://idtesis.com disadur pada 6 September 2020 Pukul 13. 00 WIB 
asjuddin.blogspot.com hubungan

$$
3 \text { tujuan hukum, }
$$

http://rasjudin.blogspot.com, disadur pada tanggal 27 Agustus 2020 Pukul 20.00 WIB. metrokaltara.com kemanfaatan hukum https://www.mertokaltara.com disadur pada tanggal 27 Agustus 2020 Pukul 20. ${ }^{40}$ WIB 
IBLAM LAW REVIEW

SEKOLAH TINGGI ILMU HUKUM IBLAM

Vol 1 No 1 2021, Hal 132-162 